\title{
General foreword
}

As summer is turning into autumn, Sweden's oldest online journal launches its $47^{\text {th }}$ issue, this time with a mainly international profile. Since the creation of the university in its present form eleven years ago, a large number of workshops and conventions have been held that involve scholars from various parts of the world. In September 2017, a workshop on the theme "Enslavement in the Indian Ocean World" convened in Kalmar, that involved twenty scholars from nine countries and four continents. The event is inductive of the increasing academic attention to a dark side of the human experience, namely slavery. However one defines a slave - and there are several definitions - the ownership over other people's lives and work has a history that far exceeds the Graeco-Roman world and the Atlantic scene, known to the public through movies such as Spartacus and Amistad. Not least, bondage and slavery have been realities in the maritime world of the Indian Ocean since ancient times. Of the papers presented at the Kalmar workshop, four are published here. These studies, by Michael Charles Reidy, Lodewijk Wagenaar, Filipa Ribeiro da Silva and Akanksha Narayan Singh, will be presented in detail in a separate introductory essay by Hans Hägerdal. Together, they highlight the human consequences of European colonialism in East and South Africa, and South Asia, and the multifaceted forms of slavery that flourished in the Indian Ocean World and have left traces into modern times.

Apart from the main theme, Hanna Söderlund, Josefine Wälivaara and Karin Ljuslinder contribute with an analysis of a slightly more cheerful subject, namely humour. In their study "Handikapptoaletten hade de som förråd' - Att utmana funktionsnormativitet med humor", the authors discuss the potential of humour to highlight and challenge norms that are often taken as granted. They do this by analysing conversations between people with disabilities, found in a podcast from the 2010s. Lastly, Robert Walldén and Annika Langwagen discuss reading strategies in a Swedish primary school in "'Man förstår nästan allt!' Läsförståelsearbete med faktatexter i årskurs 4". Here, they report from a classroom study undertaken in an "exposed area" with many immigrant pupils, conducting subject-integrated work with nonfiction texts and reading strategies in the class.

For the editorial board

Hans Hägerdal 